інформаційної компетентності, бо це надійніший і триваліший чинник, ніж знання зі спеціальності, які з часом втрачають актуальність. На нашу думку, запропоновані завдання уможливлюють формування означеного компонента професійної підготовки особистості, а також забезпечують багатовимірність iii руху в освітньому просторі.

\title{
Література
}

1. Буряк В. Умови та засоби самоосвіти студентів / В. Буряк // Вища школа. 2002. -№ 6. - C. 18-29.

2. Вікторенко І.Л. До питання про принципи організації самостійної роботи студентів / І.Л. Вікторенко // Вісник Черкаського університету. Серія педагогічні науки. Випуск 88. - Черкаси, 2006. - С. 9-13.

3. Рогова О.В. Формування пізнавальної активності студентів у процесі самостійної роботи / О.В. Рогова // Напрями наукових досліджень кафедри педагогіки. Педагогіка та психологія: [зб. наук. праць] ; за ред. В.І.Лозової. - Харків, 1997. - С. 39-41.

4. Ткаченко М.В. Самостійна робота студентів як чинник професійного становлення майбутнього фахівця / М.В. Ткаченко // Наука і освіта. - 2008. - №1-2. C. $107-110$.

Стаття надійшла до редакції 15.04.2012 р.

УДК 371.15

В. В. Шинкаренко,

acnipaнm,

Криворізький педагогічний інститут

ДВНЗ «Криворізький наиіональний університет»

\section{ЕТНО-ХУДОЖНЯ КУЛЬТУРА ЯК СКЛАДНИК ПРОФЕСІЙНОЇ КОМПЕТЕНТНОСТІ МАЙБУТНЬОГО ВЧИТЕЛЯ}

\begin{abstract}
Шинкаренко В.В. Етно-художня культура як складова професійної компетентності майбутнього вчителя.

У статті шилхом зіставлення, порівняння, узагальнення наукової інформації обтрунтовано слушність організачії навчального прочесу на основі народних традицій. Розкрито засоби й методи народного виховання, запропоновано рекомендаџї̈ з практичного використання отриманих результатів задля ефективного формування компетентності майбутнього вчителя.

Ключові слова: етно-художня культура, народне виховання, народні традииіі.

Шинкаренко В.В. Этно-художественная культура как составляющая профессиональной компетентности будущего учителя.

В статье на основе сопоставления, сравнение, обобщение научной информации обосновывается иелесообразность организации учебного прочесса на основе народных традиций. Раскрыты средства и методы народного воспитания, предлагаются рекомендачии с практического использования полученных результатов, с иелью компетентности будущего учителя.

Ключевые слова: этно-художественная культура, народное воспитание, народные традиции.

Shinkarenko V. Ethno-art culture as a component of professional competence of future teachers.

In the article on the basis of comparison, comparison, synthesis of scientific information, it is proposed teaching learning process, based on folk traditions. Means and methods are disclosed of public education, with recommendations to the practical use of the results, to the competence of future teachers.

Key words: ethnic and artistic culture, popular education, folk traditions.
\end{abstract}

Постановка проблеми. Перехід українського суспільства на новий етап - етап побудови незалежності держави - зумовив необхідність 
розв’язання завдань, пов'язаних з розвитком духовної культури особистості, оскільки їй належить визначна роль у формуванні нової людини - освіченої, вихованої, культурної, здатної до самоосвіти, саморозвитку.

Складовою частиною духовної освіченості школяра $\epsilon$ етно-художня культура, у структурі якої значне місце належить народним традиціям та звичаям. Дитина постійно перебуває під постійним виховним впливом матеріальної і духовної культури свого народу. Це потрібно, найперше, для найповнішого розкриття природних схильностей дитини i розвитку здібностей виявлення етнопсихологічних особливостей. Однак сучасна етнокультурна ситуація в Україні, особливо на Півдні та Сході, відмінна від тієї, яка потрібна для повноцінного, духовного та інтелектуального відродження народу. Діти не залучаються 3 раннього віку до культури та історії рідного народу, оскільки не перебувають під безпосереднім формувальним впливом українського середовища. Не використовують повною мірою своїх можливостей заклади народної освіти, хоча протягом останніх років і відбулися значні зрушення в українському шкільництві. Слід наголосити на необхідність широкого впровадження виховної роботи у школі заходів саме на основі народних традицій.

Публікації з теми дослідження. Цілісна система виховання школярів на національно-культурних традиціях у педагогічній літературі висвітлена вкрай недостатньо. 3 даної проблеми останнім часом 3'явилося чимало праць істориків і філософів, але вони, як правило, носять щодо педагогіки опосередкований, загальний характер (К. Булашев, Я. Володимирський, О. Забужко, М. Жулинський, В. Іванишин, С. Павлюк, М. Попович, В. Сверстюк, О. Субтельний, В. Шинкарук, В. Яремчук та інші).

Нині дещо краще розкриті питання патріотичного, екологічного та естетичного виховання молоді на національно-культурних традиціях українського народу (П. Ігнатенко, Н. Косарєва, В. Пошгужний, Г. Шевченко). Слід зазначити, що стосовно цієї проблеми накопичено значний фактичний матеріал 3 досвіду окремих педагогічних колективів національних шкіл та учителів, який потребує свого узагальнення, наукового пояснення, проникнення в сутність емпіричного викладу педагогічних явищ і процесів.

На сучасному етапі розвитку педагогічної науки окремі аспекти виховання учнів загальноосвітніх шкіл на національних культурних традиціях українського народу розглядались у дослідженнях: А. Бойко, Р. Дзвінки, О. Дубасенюк, П. Ігнатенко, В. Кузя, Ю. Руденко, М. Стельмаховича, В. Струманського, В. Попружного, Г. Шевченко. Однак педагогічний потенціал національно-культурних традицій у початковій школі остаточно не розкрито.

Мета статі. Вивчити наукову літературу й інші джерела дослідження з окресленої проблеми, зробити їх аналіз для теоретичного обгрунтування навчального процесу на основі народних традицій. Розкрити засоби й методи народного виховання, розробити рекомендації 3 практичного використання отриманих результатів. 
Отримані результати. Наукові дослідження переконливо доводять, що дитина має знаходитись під постійним виховуючим впливом матеріальної і духовної культури свого народу. Це потрібно, найперше, для найповнішого розкриття природних схильностей дитини $\mathrm{i}$ розвитку здібностей, виявлення етнопсихологічних особливостей. Тут мається на увазі не лише загальний процес демократизації школи, а виникнення нових концепцій та дисциплін, до яких входять і народознавство, проведення виховних годин, конкурсів та свят з використанням народних традицій.

Вивчення стану виховної роботи з використанням народних звичаїв, обрядів та традицій у психолого-педагогічній науці та практиці роботи сучасної школи дозволяє нам зробити висновки про те, що наявні суперечності у розв'язані проблеми. Допомогти вчителям у розв'язанні проблем можливо лише за умов озброєння їх знаннями з історії виникнення народних традицій, звичаїв та обрядів, створення певних методичних посібників. Нами під час експерименту було використано анкету для студентів першого курсу.

Анкета містила такі питання: «Що таке традиція?», «Що таке обряд?», «Що таке звичай?», «Які традиції притаманні твоїй родині?»

Студенти $45 \%$ ознайомленні 3 поняттям «народні традиції», знають $34 \%$, що треба враховувати народні традиції при святкуванні, таких свят, як Пасха, Різдво, але Водночас не знають конкретних звичаїв і чому це свято так святкується $21 \%$. У ході констатуючого експерименту було виокремлено три рівні етно-художньої культури студентів: низький, середній, високий.

I рівень - високий:студенти активно приймають участь у пізнавальній діяльності, здатні розповісти про традиції та звичаї свого народу. А також знають багато народних українських пісень, ігор та прикмет. Найважливіше те, що все це застосовується на практиці і не тільки дітьми, а й у колі сім'ї.

II рівень - середній: студенти виявляють інтерес до пізнання народних традицій, звичаїв, обрядів свого народу. Цей рівень властивий для тих студенти, які мають певні знання, але застосувати їх на практиці не можуть. Студенти на уроці музики не завжди активні й уважні.

III рівень - низький: у студентів спостерігається байдужість до пізнання традицій та звичаїв свого народу. Підлітки цього рівня характеризуються відсутністю теоретичних знань своєї культури, а також відсутності знань про народні пісні та ігри. Вони пасивні та неуважні на заняттях.

Таблиия 1

Визначення рівнів сформованості етно-художньої культури (\%)

\begin{tabular}{|l|c|c|c|}
\hline \multicolumn{1}{|c|}{ Рівні } & Низький рівень & Середній рівень & Високий рівень \\
\hline $\begin{array}{l}\text { Середній } \\
\text { показник }\end{array}$ & 71,3 & 21,9 & 6,8 \\
\hline
\end{tabular}


Із результатів таблиці ми бачимо, що переважає низький рівень. Висновок студенти погано знають народні традиції і не знають їх виникнення та як їх застосовувати на практиці. студенти не подобаються заняття з музичних дисциплін. Причини цього, ми вважаємо, що викладачі не цікаво пояснюють матеріал, погані підручники, мало часу відводиться на вивчення теми народні традиції у житті людини та їх вплив на розвиток духовності особистості.

У своєму досліджені, ми провели тестування на визначення знань студентів 3 теорії володіння народними традиціями. Наведемо зразок тесту.

\section{Тест}

1. Кожна нація має свої звичаї, що виробилися протягом...?

a) багатьох століть

б) одного століття

в) кілька років

2. Елемент соціальної і культурної спадщини, який передається наступним поколінням і зберігається протягом тривалого часу в суспільстві - це...?

a) обряд

б) звичай

в) традиція

3. «Той, хто забуває звичаї своїх батьків, карається людьми і Богом. Він блукає по світу, як блудний син, і ніде не може знайти собі пристановища, бо він загублений для свого народу». Це що?

а) прикмета

б) повір'я

в) звичай

4. Народна гра у жмурки - «киці-баба» - це...?

a) весняна гра

б)уривок із ритуалу

в) дитяча гра

5. Різдвяний день вважається народженням...?

a) Ісуса Христа

б) Петра 1

в) Святого Миколая

6. Напередодні якого свята жінки випікали обрядове печиво «жайворонків», та давали дітям, щоб ті закликали весну?

a) на Масницю

б) на Благовіщення

в) на Стрітення

7. Купальське дерево уособлює що...?

а) Дерево смерті

б) Дерево життя

в) Дерево нещастя

8. Як люди вітаються один до одного на Паску?

a) Добрий день

б) зовсім не вітаються

в) Христос воскрес. 
Констатувальний експеримент показав, що найбільший процент негативних відповідей - 69,5\% - 71,3\%,отримано середні оцінки - 21,9\% $22,7 \%$. I лише 6,8\%-7,8\% отримали високі оцінки. Причинами переважання низького рівня - це відсутність необхідної системи навчання, яка б дозволяла здійснити перехід від низького рівня знання до високого. Задля виявлення ставлення викладачів до використання ігрових ситуацій на заняттях ми провели анкетування, яке включало такі питання:

1) Чи вважаєте Ви за необхідне впроваджувати ігрові ситуації 3 використанням народних традицій для формування етно-художньої культури?

2) Чи застосовуєте Ви ігрові ситуації на заняттях з музики? Які саме?

3) Чи дотримуєтесь Ви думки, що використання ігрових ситуацій 3 використанням народних традицій, може поліпшити пізнавальні здібності студентів з предмету?

Результати дослідження показали, що більшість викладачів уважають впровадження ігрових ситуацій з використанням народних традицій на заняттях 3 музичних дисциплін необхідною умовою, але на практиці застосовують не дуже часто. Провівши анкетування та бесіду з викладачами факультету мистецтв ми можемо зробити висновок: практичне застосування ігрових ситуацій в шкільній практиці на заняттях з музичних дисциплін має недостатній рівень.

У процесі фахової підготовки майбутнього вчителя музики, на наш погляд треба звернути увагу на компетентністний підхід, який включає в себе моделювання результатів навчання і їх втілення як норм якості освіти (система забезпечення якості). Під результатами розуміються набори компетентностей та компетенцій, що включають знання, уміння і навики.

Метою компетентністного підходу є формування в людині здатності і готовності результативно діяти за межами навчальних сюжетів, ситуацій, ефективно розв'язуючи життєві, соціальні або професійні проблемні завдання. Етно-художня культура $є$ складовою компетенції майбутнього вчителя музики. Водночас, як засвідчило наше дослідження, у вищій школі не приділяється важливої уваги цій проблемі. Компетенції - це узагальнені способи дій, що забезпечують продуктивне виконання професійної діяльності. Це здібності людини реалізовувати на практиці свою компетентність. Ядром компетенції є діяльнісні здібності - сукупність способів дій [3].

Компетенції можна визначити як сукупність здібностей реалізації свого потенціалу (знань, умінь, досвіду) для успішної творчої діяльності 3 урахуванням розуміння проблеми, представлення прогнозованих результатів, розкриття причин, що утруднюють діяльність, пропозиції засобів для усунення причин, здійснення необхідних дій i оцінки прогнозованих результатів [2]. Компетениії - це інтеграційна цілісність знань, умінь і навичок, що забезпечують професійну діяльність, це здатність людини реалізовувати на практиці свою компетентність. Оскільки реалізація компетенції відбувається в процесі виконання різноманітних видів діяльності для розв'язання теоретичних і практичних задач, то в структуру компетенції, крім діяльнісних (процедурних) знань, умінь і навиків, входять 
також мотиваційна i емоційно-вольова сфери. Важливим компонентом компетенції є досвід - інтеграція в єдине ціле засвоєних людиною окремих дій, способів і прийомів розв'язування задач [1, с 23-30].

При проведені занять з музичних дисциплін можливо використовувати народний календар при вивченні тем: «Пісенність, танцювальність, маршовість», «Музичний настрій зимових свят», «Свято колядок, щедрівок та віншувань». Під час підготовки свят, звичаїв i обрядів народного календаря, студенти проймаються глибокими патріотичними почуттями, життєстверджуючим оптимізмом, почуттям хазяїна рідної землі. При цьому вони успішно опановують трудовими вміннями й звичками, народною мораллю, естетикою, побутовою культурою, нормами поведінки. При вивченні українських народних пісень на заняттях музики, студенти чуйно відгукуються на все, що торкається їхніх почуттів і уяви. А це в свою чергу сприяє формуванню етно-художньої культури майбутнього вчителя.

Висновки. Педагогічна сутність етно-художньої культури полягає у відтворенні в наступних поколінь того кращого, що вироблено українським народом упродовж усієї історії свого існування. Отже, виховання студентів на національно-культурних традиціях українського народу, забезпечує їх долучення до високих духовних i матеріальних надбань свого народу, засвоєння i примноження кращих звичаїв, формування етно-художньої культури, моральних норм, естетичних цінностей та інших елементів культурної спадщини, якостей українського народу, специфіки його емоційної та інтелектуальної сфери, що зберігаються нацією, розвиваються і передаються протягом століть. Нами з'ясовано, що компетентність, по суті, визначає систему взаємовідносин набутих знань, вмінь і навичок і здатності ефективно використовувати їх в реальній практичній діяльності. Ми трактуємо компетентність як володіння людиною відповідною компетенцією, що включає його особистісне відношення до неї і предмету діяльності; а компетенції як узагальнені способи дій, що забезпечують продуктивне виконання професійної діяльності. Компетенції передбачають: знання і розуміння (теоретичні знання, здібність знати й розуміти); знання як діяти (практичне оперативне застосування знань до конкретних ситуацій); знання як бути (цінності, що є невід’ємною частиною сприймання життя 3 іншими в соціальному контексті). Подальшу свою роботу ми вбачаємо у розробленні спеціальних завдань 3 формування етно-художньої культури майбутніх учителів музики.

\section{Література}

1.3еер Э. Компетентностный подход к модернизации профессионального образования/ Э.Зеер, Э.Симанюк// Высшее образование в России. - 2005. - № 4. - С. 23-30.

2.Стрюков М.Б. Компетентностый поход в подготовке специалистов по информационной безопасности в ГОУ СПО РКСИ / М.Б.Стрюков, М.И.Сущенко, П.П.Беленький: [Электронный ресурс] :http://www.rksi.ru/rksi

3.Хуторской А.В. Ключевые компетенции и образовательные стандарты /А.В. Хуторской // Интернет-журнал «Эйдос». - 2002:[Электронный ресурс] :http://www.eidos.ru/journal/2002/0423.htm

Стаття надійшла до редакції 12.04.2012 p. 